\title{
Factors affecting to long-term relationship of outsourc- ing: A case study of Thailand
}

\author{
Thitiporn Katato ${ }^{1}$, Natt Leelawat ${ }^{2 *}$, Jing Tang ${ }^{3}$ \\ ${ }^{1}$ Department of Industrial Engineering, Faculty of Engineering, Chulalongkorn University, Bangkok, Thailand \\ ${ }_{1,2}$ Disaster and Risk Management Information Systems Research Group, Chulalongkorn University, Bangkok, Thailand \\ ${ }^{3}$ International School of Engineering, Chulalongkorn University, Bangkok, Thailand
}

\author{
Keywords \\ Outsourcing \\ Outsourcing performance \\ Outsourcing long-term relation- \\ ship \\ Thailand
}

Received: 9 August 2019

Accepted: 13 September 2019

Published: 31 October 2019

\begin{abstract}
This research focuses on the analysis of finding factors that positively affect the long-term relationship of outsourcing. A model is being proposed that suggested that cooperation, control, and improvement can affect performance and then further affect outsourcing long-term relationships. Using a data set collected from 322 questionnaire surveys via e-mail and 200 questionnaire surveys sent to personal to test the proposed hypotheses from June 1 to June 30, 2019. As a result, 219 respondents were used for data analysis (41.95 percent). This study utilizes Partial Least Squares (PLS) to confirm the hypotheses-a variance-based Structural Equation Modeling (SEM) approach. The results showed that at 0.05 significance level, cooperation has a positive effect on the control. Moreover, cooperation and improvement have a positive effect on the performance, and performance has a positive effect on outsourcing long-term relationships. This study suggests that outsourcing suppliers in Thailand maintain or extend their outsourcing relationships with their current customers.
\end{abstract}

(c) 2019 The Author(s). Published by TAF Publishing.

\section{INTRODUCTION}

Outsourcing refers to the use of external agents to perform an organization general activity, When the organization has outsourcing, organization has various advantage, such as cost-reduction, access to specialized resources, quality improvement, higher quality services from providers and focus on core business activity (Lee, Shin, Hwang, Kuper, \& Kang, 2018; Rijal, 2016). Besides the cost savings, organizations are increasingly outsourcing to changing business processes (Levina \& Su, 2008).

Although outsourcing has various benefits, as described above, and growing trend, research Bharadwaj, Saxena, and Halemane (2010) has found that the rate of outsourcing failure is still high. A survey Goo, Kishore, Nam, Rao, and Song (2007) showed that many clients decided to change service provider unexpectedly due to factors, such as lack of satisfaction with seller performance, work cooperation, conflicts according to general agency issues or changes in conditions, including new requirements arising after the out-

\footnotetext{
${ }^{*}$ corresponding author: Natt Leelawat

†email: natt.l@chula.ac.th
}

sourced contract.

The BPO and Information Technology Outsourcing (ITO) situation in Thailand in the past few years cannot deny that Thailand is recognized as a famous country and is being watched as a center and excellence outsourcing. Software industry and manufacturing centers are a clear and consistent evidence of leadership in the global market. There is also explicit evidence that many local companies have outsourcing success fully. Also, an international recognition presented that Thai software is an innovation that exemplifies technical expertise and gains international standards (Sutton, 2017).

Figure 1 shows that the problem for the Thailand down from Rank 6 to Rank 8 for Offshoring BPO and ITO. For this year's index, Thailand dropped to second place, which has been specified in previous years index that failure in industrial development and IT services are the main reason and most of these problems cannot be solved (Sethi \& Gott, 2017). 


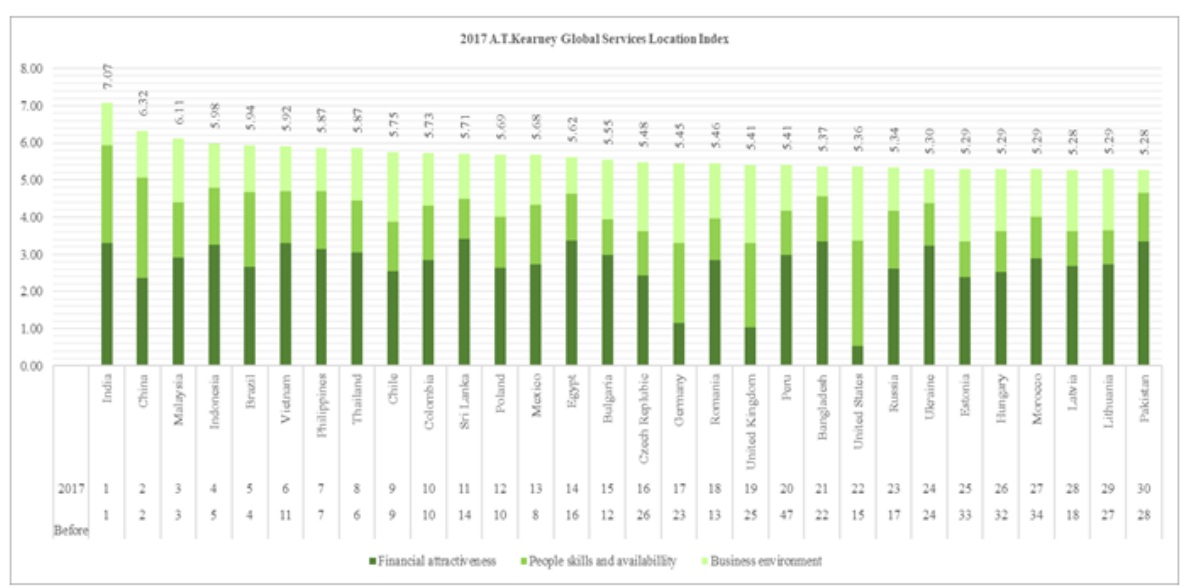

FIGURE 1. Adapted from Global offshoring BPO and ITO (Sethi \& Gott, 2017).

However, there is a lack of clear evidence about the differences of the previous study. From the above reasons, the organization should be a study of the company that was hired by the important point to focus on the factors that affect the BPO contract duration. One major reason for the challenges posed by outsourcing is the issues related to managing the outsourcing relationship.

Next, this study pays attention to the outsourcing situation. Consequently, this study focuses on investigating factors affecting to long-term relationship of outsourcing. The target group for answering the questionnaire must be people with a section-head position or higher and involved in an outsourcing project or has the right to decide to hire or terminate an outsourcing contract. Questionnaire was distributed through online platform. Proposed model is tested structural model and hypothesis by Partial Least SquaresStructural Equation Modeling (PLS-SEM). Which explain in detail about research methodology in section 4 . For section 2 is described about literature review. Section 3 is about proposed research model and hypothesis then section 4 showed the results. And the last section, it is discussion and conclusion.

\section{LITERATURE REVIEW \\ Outsourcing Overview}

Outsource process makes the company focus on the main activities or important activities notified employees of the importance of activities received from major activities and important work activities, divided into 1.) Main activities are work activities necessary for the company's existence, such as product manufacturing, product design and 2.) Important activities are an important job that may affect the organization's operations, such as procurement of raw materials for production, customer care (Kern \& Willcocks, 2000; Kuo \& Chen, 2015). The most outsourcing research (Gopal, Mukhopadhyay, \& Krishnan, 2002; Lacity, Khan, Yan,
\& Willcocks, 2010) focus on decision making. By answering the question that what task do you want to outsource? why to outsource? who to outsource? how to outsource? and research related to the outsourcing outcome. It also shows various ways to measure outsourcing success, such as the general perception of customers of success, quality relationships, outsourcing performance and the ability to manage resources.

BPO means to assignment one or more business processes to the outside company to be the operator and take responsibility instead. To be able to achieve the company's goals (Bharadwaj et al., 2010; Willy, 2017). ITO is the use of a third-party vendor to provide IT products and services. ITO provides a number of services, including IT infrastructure (hardware and operating systems), applications development, and others (Bustinza, Arias-Aranda, \& GutierrezGutierrez, 2010).

Measurement of BPO/ITO outcomes are difference. The first one, ITO outcomes are classified into three categories; performance, relationship quality and capability (Lacity et al., 2010). While BPO outcomes are more diverse and measure many aspects more than ITO, there are; performance improvement, relationship quality and relational governance, effective knowledge sharing, trust, commitment, capability and client-vendor agreement (Lacity, Solomon, Yan, $\&$ Willcocks, 2011). The success of the BPO depends on the level of cooperation between the hiring partners and the reduced relationships can lead to high financial costs, disruption in operations and loss of business opportunities (Goo, Kishore, Rao, \& Nam, 2009). In the past, researches (Lacity et al., 2010, 2011) show that outsourcing focuses only on cost reduction before outsourcing is complicated and increasing emphasis on innovation, including business transformation. 
It appears that outsourcing is beneficial actually to the organization. Also, organizations are starting to outsource widely. One major reason for the challenges posed by outsourcing is issues related to managing the outsourcing relationship. For a competitive advantage that is constantly changing, organizations should choose quality service provider and maintain long-term outsourcing relationships.

\section{Factors}

This research focuses on the analysis of finding factors that have a positive effect on long-term relationship of outsourcing. So, this section describes the relevant factors. We decided to use these factors; Control (CT), Cooperation (COOP), Proactive Improvement (PI), Outsourcing Performance (OP), and outsourcing Long-Term Relationship (LT) because these factors still have some gaps that still cannot be analyzed as how does it affect other factors. In this part, we explain each factor used in the proposed research model.

\section{CT}

Control systems have been categorized in various ways: formal versus informal controls, behavior versus outcome controls; mechanistic versus organic controls etc.

\section{COOP}

Definitions have been mentioned a lot in literature related to vendor-client relationship. However, concluded that cooperation can demonstrate the sharing of useful information and can be used for real between companies which will be related to activities such as setting goals, teamwork, unity, support each other and ready to work together to achieve goals (Larson \& Kulchitsky, 1999).

\section{PI}

An idea, practice, or object that is seen as something new by the person or group of people who apply. Agreeable with the research (Engelbrecht, 2004) that shows the strong impact in achieving the goal. Proactive improvements will focus on the scope and concentration of activities that employees focus on. On the other hand, these innovations will affect the perceived effectiveness of the employment relationship. Including the development of new operational processes for maximum efficiency (Engelbrecht, 2004).

\section{OP}

Some authors agree that performance is very complicated naturally. In the first studies (Stank, Goldsby, Vickery, \& Savitskie, 2003), the proposed three-dimensional concepts include areas of operational performance, relational per- formance, and cost performance. Another research suggested to measure the performance of outsourcing from goal achievement and information exchange (Engelbrecht, 2004).

\section{LT}

Reflect the expectations of performance awareness. It also depends on the function of two main factors which are independence and the extent to which they trust each other. Both independence and trust related to environmental instability, transaction-specific investments, corporate reputation, and satisfaction with clients-customers' relationships (Dibbern, Goles, Hirschheim, \& Jayatilaka, 2004).

\section{RESEARCH METHODOLOGY \\ Proposed Research Model And Hypotheses}

We focus about Outsourcing performance and BPO longterm relationship therefore we explore the factors leading to positive effects to BPO contract duration from the supplier-customer relationship perspective. Which shown in Figure 2.

There are research indicates control of the service provider mechanism in a manner that is beneficial to the client's organization. Not only process control but also process control [18]. (a.) Process control refers to the control of methods and procedures that outsourcing companies perform. Which should comply with the conditions stipulated in the contract between outsourcing and customers (Tiwana, 2008). It also ensures customers that outsourcing is using the right process to reduce errors and unnecessary correction, including wasteful use of resources to increase work efficiency. (b.) Outcome control explains what should be accomplished in the outsourcing project. Likewise, customers can provide feedback efficiently by evaluating the outcome (Love \& Josephson, 2004). Absolutely, the desired outcomes and assessment criteria are contractual requirements as well as process control (Tiwana, 2008). Consequently, we expect both types of formal control mechanisms to enhance BPO performance.

H1: Control exerts a positive effect on the performance of outsourcing projects.

In outsourcing project, impacts of cooperation could be causes of an outsourcing contract. For example, have a research demonstrated that communication influences logistics outsourcing performance. So, we would like to investigate how cooperation affect outsourcing. Then, the following hypotheses are set.

H2: Cooperation positively affects the outsourcing performance without control. 
However, lack of evidence that cooperation will enhance the positive impact of control on the performance of BPO projects. We think cooperation will support control so in this research we decided to set $\mathrm{H} 3$ to fill the gap.

H3: Cooperation will enhance the positive impact of control on the performance of outsourcing projects.

From section 2, proactive improvement for this research we designed it like an innovation. Innovations are studied as independent variables or dependent variables. As an independent variable, researchers have investigated at a limited level. To check on innovations that are motivation for outsourcing decisions. As the dependent variable researchers have examined the impact of innovation. That is the result of outsourcing innovation (Lacity et al., 2010, 2011).

Consequently, proactive improvement should be effect on outsourcing performance. The following hypothesis is set.

H4: Proactive Improvement positively affects the outsourc- ing performance without control.

Previous study (Deepen, Goldsby, Knemeyer, \& Wallenburg, 2008) lack of evidence that cooperation will enhance the positive impact of control on the performance of BPO projects. However, we think proactive improvement will support control so in this research we decided to set $\mathrm{H} 5$ to fill the gap.

H5: Proactive Improvement will enhance the positive impact of control on the performance of outsourcing projects. We consider outsourcing performance is refer to clients' perception of outsourcing capability, such as reliability, relevancy, timeliness, accuracy, currency, completeness of information including to overall satisfaction. In this research, we think that effective outsourcing leads to outsourcing long-term relationship.

H6: There is a positive relationship between the outsourcing performance and outsourcing long-term relationship.

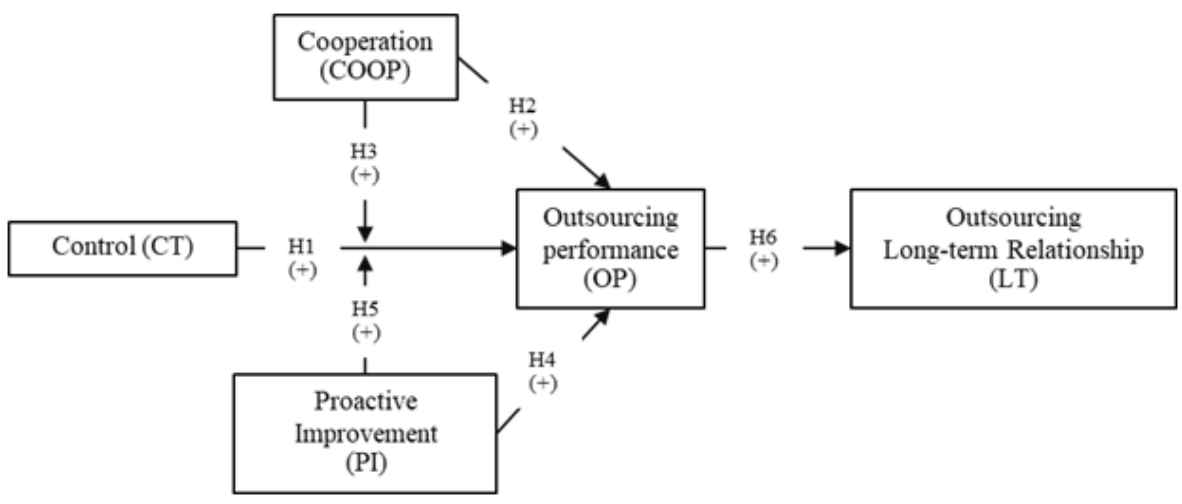

FIGURE 2. Proposed research model

\section{Control Variables}

Other variables could also influence the outsourcing of longterm relationships. The first ones are the size of the client and the size of the service provider. Because we believe it is possible that larger organizations are more likely to commit to long-term deals and have sufficient resources and the ability to support the process for outsourced activities and any assets. Therefore, we choose to have these variables as control variables.

\section{Quesionnaire Design}

The questionnaire has six sections, start with demographics profile, about outsourcing, an outsourced activity, question related 5 factors that adapted from research (Deepen et al., 2008). The response format will be standardized using a five-point Likert scale by ranging from $5=$ "Strongly Agree", 4 = "Agree", 3 = "Neutral", 2 = "Disagree" and 1 = "Strongly Disagree".

\section{Back translation checking}

For this research, the original questionnaire is in English. After that we have translated into Thai. Then it was examined by four Thai native speaking who have never seen this questionnaire before and there is no outsourcing background to reduce data bias is to check the content of each topic as the original (validity checking). It has been revealed that there were some incorrect translation and words.

\section{Data collection}

This study focuses on the companies in Thailand which are using BPO. The questionnaires will be distributed to executive or managerial positions in the department(s) which is an outsourcing user. The desired sample included small to large organizations across diverse industries that had outsourced one or more business process. The normative response rates based on pre committed samples are as high as 40 percent (Anderson \& Narus, 1990). As with factor analysis, for a simple model, 200 cases might be adequate when 
relationships among components of the model are strong (Wong, 2013).

The target group must be the person involved in an outsourcing project or has the right to decide to hire or terminate an outsourcing contract.

\section{Hypotheses testing: PLS-SEM}

The structure of developed model is examined by PLS-SEM method which is suitable when sample size is small and research objective focuses on prediction (Hair, Sarstedt, Pieper, \& Ringle, 2012). Due to, measurement scale of the model is the reflective model. Reliability and validity should be examined for factors' quality. Then, we improved model for more effective. After that, path coefficient is assessed to show significant relationships.

\section{RESULTS}

\section{Descriptive Results}

The overall response rate is $41.95 \%$. The total samples are 219. $51.60 \%$ is female, $48.40 \%$ is male, which has quite similar values. The most respondents around $30.59 \%$ are between 40-50 years-old. Company type is categorized into 11 types. $18.72 \%$ is working about financial (e.g., banking and insurance). Work position is categorized into $4 \mathrm{lev}-$ els, which up to section head position. $34.25 \%$ is middle- level manager. And the last one, outsourcing type is categorized into 9 groups, which $26.48 \%$ outsourced Information Technology/Information System following by maintenance, manufacturing, and the least outsourcing is others types such as, laborer, sale, and construction worker equal to $1.83 \%$ (see Table 1 ).

\section{Measurement Model}

At first, proposed research model is assessed measurement model. Table 1 presented outer loadings. It is expected higher than 0.7 (Afthanorhan, 2014). Then, composite reliability ( $\mathrm{CR} \geq 0.70$; acceptable confirmatory purpose) or Cronbach's alpha refers to internal consistency reliability, which minimum acceptance is 0.7 (Fornell \& Larcker, 1981). It examines the degree to which individual item could reflect a factor converge in comparison to other items related different factors. Convergent validity represents the common variance between items and their factors. It is checked from Average Variance Extracted (AVE) that greater than 0.5 is confirmed (Fornell \& Larcker, 1981). Table 3 shows acceptable values of overall factors in both of internal consistency reliability and convergent validity. Discriminant validity which shows correlation among factors is presented in Table 4.

TABLE 1. Profiles of respondents

\begin{tabular}{|c|c|c|c|}
\hline Category & Classification & Frequency & Percentage \\
\hline \multirow[t]{7}{*}{ Gender } & Female & 113 & 51.60 \\
\hline & Male & 106 & 48.40 \\
\hline & Age Below 30 years & 64 & 29.22 \\
\hline & More than $30-40$ years & 31 & 14.16 \\
\hline & More than $40-50$ years & 67 & 30.59 \\
\hline & More than $50-60$ years & 48 & 21.92 \\
\hline & More than 60 years & 9 & 4.11 \\
\hline \multirow[t]{8}{*}{ Company type } & Agro \& food industry (e.g., food and beverage) & 25 & 11.42 \\
\hline & $\begin{array}{l}\text { Consumer products (e.g., fashion, home and office products, phar- } \\
\text { maceuticals and personal products) }\end{array}$ & 28 & 12.79 \\
\hline & Financials (e.g., banking and insurance) & 41 & 18.72 \\
\hline & $\begin{array}{l}\text { Industrials (e.g., automotive, materials \& machine, packaging, print- } \\
\text { ing materials) }\end{array}$ & 35 & 15.98 \\
\hline & Property and onstruction (e.g., construction materials) & 32 & 14.61 \\
\hline & $\begin{array}{l}\text { Services (e.g., commerce, media, tourisms, transportation and logis- } \\
\text { tics) }\end{array}$ & 29 & 13.24 \\
\hline & $\begin{array}{l}\text { Technology (e.g., electronic components, communication technol- } \\
\text { ogy, website design) }\end{array}$ & 17 & 7.76 \\
\hline & Others & 12 & 5.48 \\
\hline \multirow[t]{4}{*}{ Position } & Top-level Managers & 57 & 26.03 \\
\hline & Middle-level managers & 75 & 34.25 \\
\hline & Supervisors & 43 & 19.63 \\
\hline & Section Head & 44 & 20.09 \\
\hline \multirow[t]{3}{*}{ Outsourcing type } & Finance/Accounting & 28 & 12.79 \\
\hline & Human Resources & 8 & 3.65 \\
\hline & Information Technology/Information System & 58 & 26.48 \\
\hline
\end{tabular}


TABLE 1. Continue..

\begin{tabular}{llll}
\hline Category & Classification & Frequency & Percentage \\
\hline Outsourcing type & Logistics & 18 & 8.22 \\
& Maintenance & 46 & 21.00 \\
& Manufacturing/Operations & 38 & 17.35 \\
& Marketing & 12 & 5.48 \\
& Services (e.g., messenger, maid, security) & 7 & 3.20 \\
& Others & 4 & 1.83 \\
\hline \hline
\end{tabular}

TABLE 2. Factor loadings

\begin{tabular}{|c|c|c|}
\hline Constructs & Items & Loadings \\
\hline \multirow[t]{3}{*}{ Control } & $\begin{array}{l}\text { CT1. The company expected the outsourcing to follow an understandable } \\
\text { written sequence of steps specified by the client toward the accomplishment } \\
\text { of project goals. }\end{array}$ & 0.681 \\
\hline & $\begin{array}{l}\text { CT2. The company expected the outsourcing to follow articulated rules and } \\
\text { procedures specified by the client toward the accomplishment of project } \\
\text { goals. }\end{array}$ & 0.746 \\
\hline & СT3. The company placed significant weight upon the timely. & 0.759 \\
\hline \multirow[t]{2}{*}{ Cooperation } & $\begin{array}{l}\text { COOP1. In the relationship with our outsourcing, we always pull together in } \\
\text { the same direction }\end{array}$ & 0.788 \\
\hline & $\begin{array}{l}\text { COOP2. When problems or questions arise during this outsourcing project, } \\
\text { we make decisions together with our outsourcing to get to adequate solu- } \\
\text { tions. }\end{array}$ & 0.795 \\
\hline \multirow[t]{3}{*}{ Proactive Improvement } & $\begin{array}{l}\text { PI1. The exchange of information between the employees of our outsourcing } \\
\text { and our company is working very well. }\end{array}$ & 0.602 \\
\hline & PI2. The outsourcing shows a high level of innovation. & 0.752 \\
\hline & PI3. Proactive Improvement supports outsourcing work control. & 0.836 \\
\hline \multirow[t]{3}{*}{ Outsourcing Performance } & $\begin{array}{l}\text { OP1. The outsourcing helps your company/organization increasing quality } \\
\text { of service. }\end{array}$ & 0.775 \\
\hline & OP2. The outsourcing has a new innovation to make your job easier. & 0.860 \\
\hline & $\begin{array}{l}\text { OP3. The outsourcing helps your company/organization increasing man- } \\
\text { agement focus. }\end{array}$ & 0.724 \\
\hline \multirow{4}{*}{ Outsourcing Long-Term Relationship } & LT1. You will continue to commit the contract with this outsourcing & 0.607 \\
\hline & $\begin{array}{l}\text { LT2. You want to extend the field to cooperation with this outsourcing part- } \\
\text { ner? }\end{array}$ & 0.868 \\
\hline & $\begin{array}{l}\text { LT3. You will recommend other project in your company to hire this out- } \\
\text { sourcing partner? }\end{array}$ & 0.870 \\
\hline & LT4. You will recommend other companies to hire this outsourcing partner? & 0.828 \\
\hline
\end{tabular}

TABLE 3. Cronbach'salpha, composite reliability and ave

\begin{tabular}{llll}
\hline \hline Constructs & Cronbach's Alpha & Composite Reliability & AVE \\
\hline Control (CT) & 0.573 & 0.773 & 0.532 \\
Cooperation (COOP) & 0.404 & 0.771 & 0.627 \\
Proactive Improvement (PI) & 0.574 & 0.778 & 0.542 \\
Outsourcing Performance (OP) & 0.691 & 0.831 & 0.622 \\
Outsourcing Long-Term Relationship (LT) & 0.821 & 0.875 & 0.641 \\
\hline \hline
\end{tabular}

TABLE 4. Discriminant validity

\begin{tabular}{llllll}
\hline \hline & CT & COOP & PI & OP & LT \\
\hline CT & 0.730 & - & - & - & \\
COOP & 0.435 & 0.792 & - & - & \\
PI & 0.223 & 0.279 & 0.737 & - & \\
OP & 0.239 & 0.389 & 0.472 & 0.788 & - \\
LT & 0.132 & 0.162 & 0.111 & 0.160 & 0.801 \\
\hline \hline
\end{tabular}




\section{Tests of Hypotheses}

Test path significant of hypothesis by PLS-SEM. The results with $p$-value of 0.05 in Table 2 indicates not only cooperation but also proactive improvement is directly significant on outsourcing performance ( $\mathrm{H} 2$ and $\mathrm{H} 4$ are accepted). On the other hand, control is not affected on outsourcing per- formance ( $\mathrm{H} 1$ is rejected). About control, cooperation is directly significant on control but not for proactive improvement, that not affected on control (H3 is accepted but $\mathrm{H} 5$ is rejected). And the last one is outsourcing performance is positive effect on outsourcing long-term relationship. (H6 is accepted).

TABLE 5. A Summary of test results from the SEM analysis

\begin{tabular}{|c|c|c|c|}
\hline Relationship & Hypotheses & $t$-value & Hypothesis Testing \\
\hline $\mathrm{CT} \rightarrow \mathrm{OP}$ & H1: Control exerts a positive effect on the performance of outsourcing projects. & 0.512 & H1: Rejected \\
\hline $\mathrm{COOP} \rightarrow \mathrm{OP}^{*}$ & H2: Cooperation positively affects the outsourcing performance without control. & $4.458^{*}$ & H1: Accepted \\
\hline $\mathrm{COOP} \rightarrow \mathrm{CT}$ & $\begin{array}{l}\text { H3: Cooperation will enhance the positive impact of control on the performance of } \\
\text { BPO projects. }\end{array}$ & $6.519^{*}$ & H3: Accepted \\
\hline $\mathrm{PI} \rightarrow \mathrm{OP}$ & H4: Proactive Improvement positively affects the BPO performance without control. & $6.983^{*}$ & H4: Accepted \\
\hline $\mathrm{PI} \rightarrow \mathrm{CT}$ & $\begin{array}{l}\text { H5: Proactive Improvement will enhance the positive impact of control on the per- } \\
\text { formance of BPO projects. }\end{array}$ & 1.512 & H5: Rejected \\
\hline $\mathrm{OP} \rightarrow \mathrm{LT}$ & $\begin{array}{l}\text { H6: There is a positive relationship between the outsourcing performance and out- } \\
\text { sourcing long-term relationship. }\end{array}$ & $2.554^{*}$ & H6: Accepted \\
\hline
\end{tabular}

* path is significant at $p$-value $<0.05$ level

** path is significant at $p$-value $<0.001$ level

* path is significant at $p$-value $<0.000$ level

\section{DISCUSSION}

From Table 3, some Cronbach's alpha values are unacceptable. In general, the acceptable alpha value should be greater than 0.7 but not more than 0.9 (Streiner, 2003). However, it has been tested that a high Cronbach's alpha value does not always mean a high level of internal consistency. That is because Cronbach's alpha is be affected by the number of items which if the number of items is too small may cause poor correlation between items. The value of Cronbach's alpha will decrease (Streiner, 2003; Nunnally, 1994). Therefore, if wanting to increase the Cronbach's alpha value, it is possible to add items which require acceptable factor loadings value.

In this research, we present a cross-loadings measurement to show the Latent Correlation Coefficients as shown in Table 6 .

TABLE 6. Cross loadings

\begin{tabular}{llllll}
\hline \hline & CT & COOP & PI & OP & LT \\
\hline CT1 & 0.681 & 0.251 & 0.209 & 0.065 & 0.144 \\
CT2 & 0.746 & 0.295 & 0.141 & 0.174 & 0.052 \\
CT3 & 0.759 & 0.382 & 0.151 & 0.250 & 0.101 \\
C00P1 & 0.379 & 0.788 & 0.120 & 0.263 & 0.127 \\
CO0P2 & 0.310 & 0.795 & 0.319 & 0.352 & 0.129 \\
PI1 & 0.145 & 0.111 & 0.602 & 0.259 & 0.056 \\
PI2 & 0.081 & 0.221 & 0.752 & 0.384 & 0.050 \\
PI3 & 0.251 & 0.260 & 0.836 & 0.385 & 0.127 \\
OP1 & 0.159 & 0.326 & 0.363 & 0.775 & 0.164 \\
OP2 & 0.200 & 0.336 & 0.355 & 0.860 & 0.085 \\
OP3 & 0.207 & 0.255 & 0.395 & 0.724 & 0.129 \\
LT1 & 0.157 & 0.120 & 0.111 & 0.055 & 0.607 \\
LT2 & 0.049 & 0.136 & 0.157 & 0.182 & 0.868 \\
LT3 & 0.157 & 0.159 & 0.017 & 0.088 & 0.870 \\
LT4 & 0.142 & 0.118 & 0.039 & 0.125 & 0.828 \\
\hline \hline
\end{tabular}

This research presented the proposed research model that emphasizes factors that affect the long-term relationship. The results of the research show that the more effective of outsourcing is resulting in the organization deciding to make a long-term contract.
From Table 5, surprisingly, $\mathrm{H} 1$ reveals that control does not have a positive effect on outsourcing performance. Although, in Table 2 and Table 3 show the acceptable value, $\mathrm{H} 1$ is rejected. Which gave the opposite results from previous research (Tiwana \& Keil, 2009), formal control (both 
process control and outcome control) have a positive effect on the outsourcing performance notwithstanding, the relationship between outcome control and performance is stronger than the relationship between process control and performance in outsourcing projects.

Lastly, for H5, this hypothesis has never appeared in literature related to outsourcing before. However, result of this research shows that proactive improvement does not support control on outsourcing performance. We think it is because of those innovations will affect working control or limit capacity development and finally affect outsourcing performance.

\section{CONCLUSION}

As outsourcing is more widely used Organizations need to have good outsourcing management. This research showed factors that have been tested correctly and appropriately. Moreover, this research presented valuable and advantage insights on how service providers in Thailand can be used for the long term and with better performance.

\section{IMPLICATIONS}

\section{Managerial Implications}

The results of this study offer clear understanding by using practices to achieve efficient outsourcing and managing long-term relationships.

The first step, when the organizations in Thailand is tend towards long-term outsourcing relationships, they need to know the factors that have been tested correctly and appropriately and can be applied for real use both to maintain long-term relationships and achieving desired outsourcing work. Important learning, when considering the business environment that is constantly changing maintaining relationships is especially important and useful for the organizations.

The second step, when deciding to make a long-term contract with a vendor, organizations need to focus on the development of their outsourcing or can be called "a specific outsourcing management strategy". In general, outsourcing management not only is development but also outsource selection and outsource evaluation. Which the development should focus on improving the ability of vendor to meet the needs of the organization in the long run (Li, Kang, \& Haney, 2017).

The last step, understanding of duties and overseeing contractual work including, the relationship between the vendor development and the efficiency of outsourcing. Which will result in the outsourcing achieving the agreed efficiency and effectiveness.

\section{Implications for research}

First, the literature related to outsourcing provides a diverse perspective on strategies or activities. In this study, we focus on outsourcing long-term relationship management but in terms of the client's long-term orientation toward service provider in the outsourcing relationship, which in comparison to other perspectives there is quite outstanding. However, due to the management of outsourcing relationships there is a close relationship between clients-service providers. Therefore, it is necessary to investigate the impact of the service provider's long-term orientation toward the clients. In addition, there is also a need for future studies to study the relationship between others which may provide interesting and useful insights for better understanding.

Second, the respondents of this research are a person who upper section head position. Therefore, decisions taking or answers to questions may be just personal opinions did not see the in-depth work of outsourcing but just looking at the overall and outcomes of the work. For the future research, we suggest that it should be inquired to staffs or employees that are close and working with those outsourcing as well to get more information to make decisions.

Third, although this study adapted the literature model to suit the Thailand outsourcing situation. It is necessary to have study in the future to study more details regarding other factors that may affect outsourcing long-term relationship. For example, the development of more complex service provider, human resource investments, management costs Including other costs such as wages. Therefore, in the future, the aforementioned factors should be considered. Including model adjustment and other factors to meet the situation at that time.

Finally, the complexity of inter-firm relationship management. For this research is a survey for outsourcing only in Thailand which the cultural differences of clients and service providers will not be different or may vary by region. Since these factors may have an effect on the relationship, considering these cultural differences in Thailand will make it more interesting for organizations to better understand the outsourcing relationship management. Lastly, if there are opportunities for future research there should be a survey from oversee companies that have outsourcing in Thailand whether to give different results or not.

\section{ACKNOWLEDGMENT}

This study has been supported by the SIIT Young Research Grant (PI: Dr. Jing Tang) from the Sirindhorn International Institute of Technology; the Ratchadapisek Som- 
poch Endowment Fund (2019), Chulalongkorn University erence no. GOLF-777742).

(762003-CC); and the EU Marie Curie project: GOLF (ref-

\section{REFERENCES}

Afthanorhan, W. (2014). Hierarchical component using reflective-formative measurement model in Partial Least Square Structural Equation Modeling (PLS-SEM). International Journal of Mathematics, 2(2), 33-49.

Anderson, J. C., \& Narus, J. A. (1990). A model of distributor firm and manufacturer firm working partnerships. Journal of Marketing, 54(1), 42-58. doi:https://doi.org/10.1177/002224299005400103

Bharadwaj, S. S., Saxena, K. B. C., \& Halemane, M. D. (2010). Building a successful relationship in business process outsourcing: An exploratory study. European Journal of Information Systems, 19(2), 168-180. doi:https://doi.org/10.1057/ ejis.2010.8

Bustinza, O., Arias-Aranda, D., \& Gutierrez-Gutierrez, L. (2010). Outsourcing, competitive capabilities and performance: An empirical study in service firms. International Journal of Production Economics, 126(2), 276-288. doi:https://doi.org/ 10.1016/j.ijpe.2010.03.023

Deepen, J. M., Goldsby, T. J., Knemeyer, A. M., \& Wallenburg, C. M. (2008). Beyond expectations: An examination of logistics outsourcing goal achievement and goal exceedance. Journal of Business Logistics, 29(2), 75-105. doi:https://doi.org/ 10.1002/j.2158-1592.2008.tb00088.x

Dibbern, J., Goles, T., Hirschheim, R., \& Jayatilaka, B. (2004). Information systems outsourcing: A survey and analysis of the literature. Advances in Information Systems, 35(4), 6-102. doi:https://doi.org/10.1145/1035233.1035236

Engelbrecht, C. (2004). Logistikoptimierung durch outsourcing: Erfolgswirkung und erfolgsfaktoren. New York, NY: SpringerVerlag.

Fornell, C., \& Larcker, D. F. (1981). Evaluating structural equation models with unobservable variables and measurement error. Journal of Marketing Research, 18(1), 39-50. doi:https://doi.org/10.1177/002224378101800104

Goo, J., Kishore, R., Nam, K., Rao, H. R., \& Song, Y. (2007). An investigation of factors that influence the duration of IT outsourcing relationships. Decision Support Systems, 42(4), 2107-2125. doi:https://doi.org/10.1016/j.dss.2006.05 .007

Goo, J., Kishore, R., Rao, H. R., \& Nam, K. (2009). The role of service level agreements in relational management of information technology outsourcing: An empirical study. MIS Quarterly, 33(1), 119-145. doi:https://doi.org/10.2307/20650281

Gopal, A., Mukhopadhyay, T., \& Krishnan, M. S. (2002). The role of software processes and communication in offshore software development. Communications of the ACM, 45(4), 193-200. doi:https://doi.org/10.1145/505248.506008

Hair, J. F., Sarstedt, M., Pieper, T. M., \& Ringle, C. M. (2012). The use of partial least squares structural equation modeling in strategic management research: A review of past practices and recommendations for future applications. Long Range Planning, 45(5-6), 320-340. doi:https://doi.org/10.1016/j.lrp.2012.09.008

Kern, T., \& Willcocks, L. (2000). Exploring information technology outsourcing relationships: Theory and practice. The Journal of Strategic Information Systems, 9(4), 321-350. doi:https://doi.org/10.1016/s0963-8687(00)00048-2

Kuo, M. P., \& Chen, Y. M. (2015). A study on the relationships among body sensory experience, customer satisfaction and customer loyalty-beauty SPA center as an example. International Journal of Business and Administrative Studies, 1(2), 61-67. doi:https://doi.org/10.20469/ijbas.10003-2

Lacity, M. C., Khan, S., Yan, A., \& Willcocks, L. P. (2010). A review of the IT outsourcing empirical literature and future research directions. Journal of Information Technology, 25(4), 395-433. doi:https://doi.org/10.1057/jit.2010.21

Lacity, M. C., Solomon, S., Yan, A., \& Willcocks, L. P. (2011). Business process outsourcing studies: A critical review and research directions. Journal of Information Technology, 26(4), 221-258. doi:https://doi.org/10.1057/jit.2011.25

Larson, P. D., \& Kulchitsky, J. D. (1999). Logistics improvement programs. International Journal of Physical Distribution \& Logistics Management, 29(2), 23-30. doi:https://doi.org/10.1108/09600039910264687

Lee, G., Shin, G.-C., Hwang, D. W., Kuper, P., \& Kang, M. (2018). How manufacturers' long-term orientation toward suppliers influences outsourcing performance. Industrial Marketing Management, 74(6), 288-297. doi:https://doi.org/10.1016/ j.indmarman.2018.07.003

Levina, N., \& Su, N. (2008). Global multisourcing strategy: The emergence of a supplier portfolio in services offshoring. Decision Sciences, 39(3), 541-570. doi:https://doi.org/10.1111/j.1540-5915.2008.00202.x 
Li, S., Kang, M., \& Haney, M. H. (2017). The effect of supplier development on outsourcing performance: The mediating roles of opportunism and flexibility. Production Planning \& Control, 28(6-8), 599-609. doi:https://doi.org/10.1080/ 09537287.2017 .1309711

Love, P. E., \& Josephson, P.-E. (2004). Role of error-recovery process in projects. Journal of management in engineering, 20(2), 70-79. doi:https://doi.org/10.1061/(asce)0742-597x(2004)20:2(70)

Nunnally, J. C. (1994). Psychometric theory 3e. New York, NY: Tata McGraw-Hill Education.

Rijal, S. (2016). The influence of transformational leadership and organizational culture on learning organization: A comparative analysis of the IT sector, Thailand. Journal of Administrative and Business Studies, 2(3), 121-129. doi:https:// doi.org/10.20474/jabs-2.3.3

Sethi, A., \& Gott, J. (2017). A.T. kearney 2017 global services location index spotlights automation as massive job displacer. Retrieved from https://bit.1y/2UDOuyl

Stank, T. P., Goldsby, T. J., Vickery, S. K., \& Savitskie, K. (2003). Logistics service performance: Estimating its influence on market share. Journal of Business Logistics, 24(1), 27-55.

Streiner, D. L. (2003). Starting at the beginning: An introduction to coefficient alpha and internal consistency. Journal of Personality Assessment, 80(1), 99-103. doi:https://doi.org/10.1207/s15327752jpa8001_18

Sutton, T. (2017). IT offshore outsourcing opportunities in Thailand. Retrieved from https://bit.1y/2UJ5ovh

Tiwana, A. (2008). Does technological modularity substitute for control? A study of alliance performance in software outsourcing. Strategic Management Journal, 29(7), 769-780. doi:https://doi.org/10.1002/smj.673

Tiwana, A., \& Keil, M. (2009). Control in internal and outsourced software projects. Journal of Management Information Systems, 26(3), 9-44. doi:https://doi.org/10.2753/mis0742-1222260301

Willy, S. (2017). Analysis of financial ratios to measure the company's performance in the sectors of consumer goods at Pt. Nippon Indosari Corpindo, Tbk and Pt. Mayora Indah, Tbk. International Journal of Business and Economic Affairs, 2(1), 45-51. doi:https://doi.org/10.24088/ijbea-2017-21006

Wong, K. K.-K. (2013). Partial Least Squares Structural Equation Modeling (PLS-SEM) techniques using smart PLS. Marketing Bulletin, 24(1), 1-32. 